\title{
ANALISA FAKTOR RISIKO PENYEBAB KEJADIAN PENYAKIT GAGAL GINJAL KRONIK (GGK) DI RUANG HEMODIALISA RS Dr. MOEWARDI
}

\author{
Siti Purwati ${ }^{1}$ \\ ${ }^{1}$ Kementerian Kesehatan Politeknik Kesehatan Surakarta Jurusan Keperawatan \\ Diterima : 4 Mei 2018, Disetujui : 11 Mei 2018
}

\begin{abstract}
Background: Chronic renal failure is a disease that affects many people of Indonesia. CRF is caused by several risk factors such as age, sex, smoking history, history of hypertension, history of diabetes, history of consumption anlagesik / NSAID, history of energy drink suplemen consumption. Based on medical record data RS Dr. Moewardi Surakarta number of patients with chronic renal failure in 2015 was 1023 patients. The purpose of this research was to analyze the risk factors associated with disease occurrence of CRF in RS Dr. Moewardi. Method: Research design used in this study design was descriptive analytic with cross sectional design. Total sample of 60 respondents from patients with CRF in Space Hemodialysis in RS Dr. Moewardi in March and April 2016 used univariate frequency distribution, bivariate chi square, multivariate logistic regression. Result: this research showed the highest frequency distribution is equal to the age of more than 60 years of 91,7\%, male gender $53,3 \%$, $53,3 \%$ smoking history, history of hypertension of 75,0\%, a history of DM $55 \%$, a history of consumption of analgesics/NSAIDs 53,3\%, a history of consumption of 90,0\% supplement drink. Bivariate analysis showed significant association between the occurrence of CRF stage 5 with age ( $p$ value 0.039), gender ( $p$ value 0.036), history of smoking ( $p$ value 0.036), hypertension ( $p$ value 0.021), DM ( $p$ value 0.016), consumption of analgesics/ NSAID ( $p$ value 0.001), supplement beverage consumption ( $p$ value 0.008 ). Results of multivariate analysis found the most dominant factor to the incidence of CRF stage 5 is a history of consumption of supplement drink with OR = 35.791. risk factors most dominant factor is a history of consumption of beverage supplements.
\end{abstract}

Keywords: Chronic Renal Failure Stage 5, Risk Factors

\section{PENDAHULUAN}

Gagal ginjal kronik merupakan perkembangan gagal ginjal yang bersifat progresif dan lambat, dan biasanya berlangsung selama satu tahun. Ginjal kehilangan kemampuan untuk mempertahankan volume dan komposisi cairan tubuh dalam keadaan asupan makanan normal (Price \& Wilson, 2006).

Angka kejadian penderita penyakit gagal ginjal kronik di Indonesia sampai sekarang belum ada data yang akurat dan lengkap, namun diperkirakan penderita gagal ginjal kronik kurang lebih 50 orang per satu juta penduduk (Suhardjono et al, 2001).

Penyakit GGK umumnya disebabkan oleh penyakit ginjal intrinsik difus dan menahun. Glomerulonefritis, hipertensi esensial, dan pielonefritis merupakan penyebab paling sering dari gagal ginjal kronik, kira-kira $60 \%$ 
(Sukandar, 2006), selain itu faktor-faktor yang diduga berhubungan dengan meningkatnya kejadian gagal ginjal kronik antara lain merokok (Ejerbald et al, 2004 dalam jurnal Restu Pranandari \& Woro Supadmi 2015), penggunaan obat analgetik dan OAINS (Fored et al, 2003 ; Levey et al, 2003 dalam jurnal Restu Pranandari \& Woro Supadmi 2014), hipertensi (Price \& Wilson, 2006), dan minuman suplemen berenergi (Hidayati, 2008 dalam jurnal Restu Pranandari \& Woro Supadmi 2015). Gagal ginjal dapat disebabkan karena usia, jenis kelamin, dan riwayat penyakit seperti diabetes, hipertensi maupun penyakit gangguan metabolik lain yang dapat menyebabkan penurunan fungsi ginjal, selain itu, penyalahgunaan penggunaan obat- obat analgetik dan OAINS baik secara bebas maupun yang diresepkan dokter selama bertahun-tahun dapat memicu risiko nekrosis papiler dan gagal ginjal kronik.

Data Kementerian Kesehatan pada tahun 2006, menyebutkan bahwa penyakit gagal ginjal menduduki peringkat 4 angka penyebab kematian di RS Indonesia (Kementerian RI, 2007).

Menurut data dari Riset Kesehatan Dasar (Riskesdas) tahun 2013 prevalensi gagal ginjal kronik di Indonesia sekitar 0,2\%. Prevalensi kelompok umur $\geq 75$ tahun dengan $0,6 \%$ lebih tinggi daripada kelompok umur yang lain.

Data Dinkes Jawa tengah (2008) menyatakan bahwa angka kejadian kasus gagal ginjal di Jawa Tengah yang paling tinggi adalah Kota Surakarta dengan 1497 kasus (25.22 \%) dan di posisi kedua adalah Kabupaten Sukoharjo yaitu 742 kasus $(12.50 \%)$.

Data rekam medis RS Dr. Moewardi Surakarta menunjukan bahwa jumlah penderita gagal ginjal kronik di
RS Dr. Moewardi surakarta tahun 2015 sekitar 1032 pasien (Rekam Medis RSDM, 2015).

Penyakit GGK disebabkan oleh beberapa faktor risiko, dengan adanya banyak faktor risiko yang menyebabkan terjadinya GGK, peneliti tertarik untuk melakukan penelitian tentang analisa faktor risiko penyebab terjadinya penyakit GGK.

\section{METODE PENELITIAN}

Rancangan penelitian pada penelitian ini adalah rancangan penelitian deskriptif analitik dengan desain penelitian cross Sectional, yaitu pengukuran atau observasi data variable depanden dan independen dilakukan pada satu waktu.

Pada penelitian ini jumlah sampel yang digunakan oleh peneliti adalah sebanyak 60 responden sesuai dengan kriteria inklusi dan eksklusi yang ditentukan. Teknik sampling yang digunakan adalah purposive sampling. Purposive sampling merupakan suatu teknik penetapan sampel dengan cara memilih sampel diantara populasi yang sesuai dengan kriteria inklusi dan eksklusi yang telah ditetapkan oleh peneliti, sehingga sampel tersebut dapat mewakili karakteristik populasi yang telah dikenal sebelumnya (Hidayat, 2014).

Instrument yang digunakan pada penelitian ini adalah lembar check list yang digunakan untuk mencacat hasil wawancara dan observasi rekam medis responden mengenai faktor-faktor risiko penyebab kejadian gagal ginjal kronis antara lain usia, jenis kelamin, riwayat merokok, riwayat penyakit hipertensi, riwayat penyakit diabetes mellitus, riwayat penggunaan obat analgesik dan 
OAINS, riwayat mengkonsumsi minuman suplemen energy.

Tahapan awal peneliti mengajukan surat permohonan ke RSUD Dr. Moewardi, khususnya dengan pihak ruangan hemodialissa dan ruangan rekam medis untuk pasien hemodialisa, kemudian menyelesaikan urusan administrasi dan selanjutnya peneliti mendatangi lokasi penelitian yaitu ruangan hemodialissa dan ruangan rekam medis untuk pasien hemodialisa RSUD Dr. Moewardi, lalu mencari responden yang sesuai dengan kriteria inklusi dan eksklusi yang telah ditentukan oleh peneliti dan melakukan penelitian.

\section{HASIL PENELITIAN}

1. Analisis Univariat

Tabel 1. Distribusi Frekuensi Berdasarkan Usia Responden

\begin{tabular}{lcc}
\hline Usia & Frekuensi & Persentase (\%) \\
\hline$>=60$ & 55 & 91,7 \\
$<60$ & 5 & 8,3 \\
\hline Total & 60 & 100,0 \\
\hline \multicolumn{3}{r}{ Tabel di atas menunjukkan bahwa }
\end{tabular}
dari 60 responden, distribusi frekuensi terbanyak pada penderita GGK adalah usia lebih dari sama dengan 60 tahun yaitu sebanyak $91,7 \%$ sedangkan yang usia kurang dari 60 tahun sebanyak 8,3\%.

Tabel 2. Distribusi Frekuensi Berdasarkan Jenis Kelamin Responden

\begin{tabular}{lcc}
\hline Jenis Kelamin & Frekuensi & Persentase (\%) \\
\hline laki-laki & 32 & 53,3 \\
perempuan & 28 & 46,7 \\
\hline Total & 60 & 100,0 \\
\hline
\end{tabular}

Tabel di atas menunjukkan bahwa dari 60 responden, distribusi frekuensi terbanyak pada penderita GGK adalah pada jenis kelamin laki-laki yaitu sebanyak 53,3\%, sedangkan yang berjenis kelamin perempuan sebanyak $46,7 \%$.

Tabel 3. Distribusi Frekuensi Berdasarkan Riwayat Merokok Responden

\begin{tabular}{lcc}
\hline Riwayat Merokok & Frekuensi & Persentase (\%) \\
\hline $\begin{array}{l}\text { Mempunyai } \\
\begin{array}{l}\text { Riwayat } \\
\text { Tidak Mempunyai } \\
\text { Riwayat }\end{array}\end{array}$ & 32 & 53,3 \\
\hline \multicolumn{1}{c}{ Total } & 60 & 46,7 \\
\hline
\end{tabular}

Tabel di atas menunjukkan bahwa dari 60 responden, distribusi frekuensi terbanyak pada penderita GGK adalah mempunyai riwayat merokok yaitu sebanyak 53,3\%, sedangkan yang tidak mempunyai riwayat merokok sebanyak $46,7 \%$.

Tabel 4. Distribusi Frekuensi Berdasarkan

Riwayat Hipertensi Responden

\begin{tabular}{lcc}
\hline Riwayat Hipertensi & Frekuensi & Persentase (\%) \\
\hline $\begin{array}{l}\text { Mempunyai } \\
\text { Riwayat }\end{array}$ & 45 & 75,0 \\
$\begin{array}{l}\text { Tidak Mempunyai } \\
\text { Riwayat }\end{array}$ & 15 & 25,0 \\
\hline \multicolumn{1}{c}{ Total } & 60 & 100,0 \\
\hline
\end{tabular}

Tabel di atas menunjukkan bahwa dari 60 responden, distribusi frekuensi terbanyak pada penderita GGK adalah mempunyai riwayat hipertensi yaitu sebanyak $75,0 \%$, sedangkan yang tidak mempunyai riwayat hipertensi sebanyak $25,0 \%$.

Tabel 5. Distribusi Frekuensi Berdasarkan Riwayat DM Responden

\begin{tabular}{lcc}
\multicolumn{1}{c}{ Riwayat DM } & Frekuensi & Persentase $(\%)$ \\
\hline $\begin{array}{l}\text { Mempunyai } \\
\text { Riwayat } \\
\text { Tidak }\end{array}$ & 33 & 55,0 \\
$\begin{array}{l}\text { Mempunyai } \\
\text { Riwayat }\end{array}$ & 27 & 45,0 \\
\hline \multicolumn{1}{c}{ Total } & 60 & 100,0
\end{tabular}

Tabel di atas menunjukkan bahwa dari 60 responden, distribusi frekuensi 
terbanyak pada penderita GGK adalah mempunyai riwayat DM yaitu sebanyak $55 \%$. sedangkan yang tidak mempunyai riwayat DM sebanyak $45,0 \%$.

Tabel 6. Distribusi Frekuensi Berdasarkan Riwayat Riwayat Mengkonsumsi Analgesik/OAINS

\begin{tabular}{lcc}
\hline $\begin{array}{l}\text { Riwayat } \\
\text { Mengkonsumsi } \\
\text { Analgesic/OAINS }\end{array}$ & Frekuensi & $\begin{array}{c}\text { Persentase } \\
(\%)\end{array}$ \\
\hline $\begin{array}{l}\text { Mempunyai } \\
\text { Riwayat }\end{array}$ & 32 & 53,3 \\
$\begin{array}{l}\text { Tidak Mempunyai } \\
\text { Riwayat }\end{array}$ & 28 & 46,7 \\
\hline \multicolumn{1}{c}{ Total } & 60 & 100,0 \\
\hline
\end{tabular}

Tabel di atas menunjukkan bahwa dari 60 responden, distribusi frekuensi terbanyak pada penderita GGK adalah mempunyai riwayat mengkonsumsi analgesic/ OAINS yaitu sebanyak 53,3\%, sedangkan yang tidak mempunyai riwayat mengkonsumsi analagesik/ OAINS sebanyak $46,7 \%$.

Tabel 7. Distribusi Berdasarkan Riwayat Riwayat Mengkonsumsi Minuman Suplemen Berenergi

\begin{tabular}{lcc}
\hline $\begin{array}{l}\text { Riwayat } \\
\text { mengkonsumsi } \\
\text { minuman suplemen } \\
\text { berenergi }\end{array}$ & Frekuensi & $\begin{array}{c}\text { Persentase } \\
(\%)\end{array}$ \\
\hline $\begin{array}{l}\text { Mempunyai } \\
\text { riwayat }\end{array}$ & 54 & 90,0 \\
$\begin{array}{l}\text { Tidak mempunyai } \\
\text { riwayat }\end{array}$ & 6 & 10,0 \\
\hline \multicolumn{1}{c}{ Total } & 60 & 100,0 \\
\hline
\end{tabular}

Tabel di atas menunjukkan bahwa dari 60 responden, distribusi frekuensi terbanyak pada penderita GGK adalah mempunyai riwayat mengkonsumsi minuman suplemen berenergi yaitu sebanyak 90,0\%, sedangkan yang tidak mempunyai riwayat mengkonsumsi minuman suplemen berenergi sebanyak $10,0 \%$.

\section{Analisa Bivariat}

Tabel 8. Hubungan antara Usia dengan

GGK

\begin{tabular}{|c|c|c|c|c|c|c|c|}
\hline \multirow[b]{2}{*}{ Usia } & \multicolumn{5}{|c|}{ GGK } & \multirow[b]{2}{*}{ OR } & \multirow[b]{2}{*}{$\begin{array}{c}P \\
\text { valu } \\
e\end{array}$} \\
\hline & $\mathrm{n}$ & $\begin{array}{c}\text { Stag } \\
\mathrm{e} \\
4\end{array}$ & $(\%)$ & $\begin{array}{c}\text { Stag } \\
\mathrm{e} \\
5\end{array}$ & (\%) & & \\
\hline$>=60$ & 5 & 8 & 72,7 & 47 & 95,9 & 0,11 & 0,03 \\
\hline tahun & 5 & & & & & 3 & 9 \\
\hline $\begin{array}{l}<60 \\
\text { tahun }\end{array}$ & 5 & 3 & 27,3 & 2 & 4,1 & & \\
\hline Total & $\begin{array}{l}6 \\
0\end{array}$ & 11 & $\begin{array}{c}100, \\
0\end{array}$ & 49 & $\begin{array}{c}100, \\
0\end{array}$ & & \\
\hline
\end{tabular}

Hasil analisis bivariat tabel di atas menunjukkan nilai $p$ value 0,039 ( $p$ value $<0,05)$ yang artinya usia mempunyai hubungan yang signifikan secara statistic dengan kejadian GGK stage 5 dengan nilai OR sebesar 0,113 berarti usia lebih dari sama dengan 60 tahun lebih berisiko terkena GGK stage 5 sebesar 0,113 kali dibandingkan dengan responden yang berusia lebih dari sama dengan 60 tahun.

Tabel 9. Hubungan antara Jenis Kelamin dengan GGK

\begin{tabular}{|c|c|c|c|c|c|c|c|}
\hline \multirow{3}{*}{$\begin{array}{c}\text { Jenis } \\
\text { Kelamin }\end{array}$} & \multicolumn{5}{|c|}{ GGK } & \multirow{3}{*}{ OR } & \multirow{3}{*}{$\begin{array}{c}P \\
\text { valu } \\
e\end{array}$} \\
\hline & $\mathrm{n}$ & Stage & $(\%)$ & Stage & $(\%)$ & & \\
\hline & & 4 & & 5 & & & \\
\hline Laki-laki & 32 & 9 & 81,8 & 23 & 46,9 & & \\
\hline & & & & & & $\begin{array}{c}5,08 \\
7\end{array}$ & $\begin{array}{c}0,03 \\
6\end{array}$ \\
\hline perempuan & 28 & 2 & 18,2 & 26 & 53,1 & & \\
\hline Total & 60 & 11 & $\begin{array}{c}100, \\
0\end{array}$ & 49 & $\begin{array}{c}100 \\
0\end{array}$ & & \\
\hline
\end{tabular}

Hasil analisis bivariate tabel di atas menunjukkan nilai $p$ value 0,036 ( $p$ value $<0,05)$ yang artinya jenis kelamin mempunyai hubungan yang signifikan secara statistik dengan kejadian GGK stage 5 dengan nilai OR sebesar 5,087 
yang berarti responden berjenis kelamin laki-laki lebih berisiko menderita GGK stage 5 sebesar 5,087 kali dibandingkan dengan responden yang berjenis kelamin perempuan.

Tabel 10. Hubungan antara Riwayat Merokok dengan GGK

\begin{tabular}{|c|c|c|c|c|c|c|c|}
\hline \multirow{3}{*}{$\begin{array}{l}\text { Riwayat } \\
\text { Merokok }\end{array}$} & \multicolumn{5}{|c|}{ GGK } & \multirow[b]{2}{*}{$\mathrm{O}$} & \multirow[b]{2}{*}{$P$} \\
\hline & $\mathrm{n}$ & Stage & $(\%)$ & Satge & $(\%)$ & & \\
\hline & & 4 & & 5 & & $\mathrm{R}$ & val \\
\hline Mempun & 32 & 9 & 81 , & 23 & 46,9 & & \\
\hline & & & 8 & & & 5 , & 0,0 \\
\hline riwayat & & & & & & 0 & 36 \\
\hline & & & & & & 8 & \\
\hline & & & & & & 7 & \\
\hline $\begin{array}{l}\text { Tidak } \\
\text { mempun } \\
\text { yai } \\
\text { riwayat }\end{array}$ & 28 & 2 & $\begin{array}{c}18 \\
2\end{array}$ & 26 & 53,1 & & \\
\hline Total & 60 & 11 & $\begin{array}{c}100 \\
, 0\end{array}$ & 49 & $\begin{array}{c}100 \\
0\end{array}$ & & \\
\hline
\end{tabular}

Hasil analisis bivariat tabel di atas menunjukkan nilai $p$ value 0,039 ( $p$ value $<0,05)$ yang artinya riwayat merokok mempunyai hubungan yang signifikan secara statistik dengan kejadian GGK stage 5 dengan nilai OR sebesar 5,087 yang berarti responden yang mempunyai riwayat merokok lebih berisiko menderita GGK stage 5 sebesar 5 kali dibandingkan dengan responden yang tidak mempunyai riwayat merokok.

Tabel 11. Hubungan antara Riwayat Hipertensi dengan GGK

\begin{tabular}{|c|c|c|c|c|c|c|c|}
\hline \multirow[b]{2}{*}{$\begin{array}{l}\text { Riwayat } \\
\text { hipertensi }\end{array}$} & \multicolumn{5}{|c|}{ GGK } & \multirow[b]{2}{*}{ OR } & \multirow[b]{2}{*}{$P$ value } \\
\hline & $\mathrm{n}$ & $\begin{array}{c}\text { Stage } \\
4\end{array}$ & $(\%)$ & $\begin{array}{c}\text { Stag } \\
\mathrm{e} \\
5\end{array}$ & $(\%)$ & & \\
\hline $\begin{array}{c}\text { Mempunyai } \\
\text { riwayat }\end{array}$ & 45 & 5 & 45,5 & 40 & 81,6 & 0,18 & \\
\hline $\begin{array}{c}\text { Tidak } \\
\text { mempunyai } \\
\text { riwayat }\end{array}$ & 15 & 6 & 54,5 & 9 & 18,4 & 8 & 0,021 \\
\hline Total & 60 & 11 & 100,0 & 49 & $\begin{array}{c}100, \\
0\end{array}$ & & \\
\hline
\end{tabular}

Hasil analisis bivariat tabel diatas menunjukkan nilai $p$ value $0,016(<0,05)$ yang artinya riwayat penyakit hipertensi mempunyai hubungan yang signifikan secara statistik dengan kejadian GGK stage 5 dengan nilai OR sebesar 0,096 yang berarti responden mempunyai riwayat hipertensi lebih berisiko menderita GGK stage 5 sebesar 0,118 kali dibandingkan dengan responden yang tidak mempunyai riwayat hipertensi.

Tabel 12. Hubungan antara Riwayat DM dengan GGK

\begin{tabular}{|c|c|c|c|c|c|c|c|}
\hline \multirow[b]{2}{*}{$\begin{array}{c}\text { Riwayat } \\
\text { DM }\end{array}$} & \multicolumn{5}{|c|}{ GGK } & \multirow[b]{2}{*}{$\begin{array}{l}\mathrm{O} \\
\mathrm{R}\end{array}$} & \multirow[b]{2}{*}{$P$ value } \\
\hline & $\mathrm{n}$ & $\begin{array}{c}\text { Stage } \\
4\end{array}$ & $(\%)$ & $\begin{array}{l}\text { sta } \\
\text { ge } \\
5\end{array}$ & $(\%)$ & & \\
\hline $\begin{array}{c}\text { Mempunyai } \\
\text { riwayat }\end{array}$ & $\begin{array}{l}4 \\
3\end{array}$ & 10 & 90,9 & 23 & $\begin{array}{c}46 \\
9\end{array}$ & $\begin{array}{c}11 \\
30 \\
4\end{array}$ & 0,016 \\
\hline $\begin{array}{c}\text { Tidak } \\
\text { mempunyai } \\
\text { riwayat }\end{array}$ & $\begin{array}{l}2 \\
7\end{array}$ & 1 & 9,1 & 26 & $\begin{array}{c}53, \\
1\end{array}$ & & \\
\hline Total & $\begin{array}{l}6 \\
0\end{array}$ & 11 & 100,0 & 49 & $\begin{array}{c}100 \\
, 0\end{array}$ & & \\
\hline
\end{tabular}

Hasil analisis bivariat tabel di atas menunjukkan nilai $p$ value 0,016 ( $p$ value $<0,05)$ yang artinya riwayat penyakit DM mempunyai hubungan yang signifikan secara statistik dengan kejadian GGK stage 5 dengan nilai OR sebesar 11,304 yang berarti responden yang mempunyai riwayat penyakit DM lebih berisiko menderita GGK stage 5 sebesar 11 kali dibandingkan dengan responden yang tidak mempunyai riwayat penyakit DM. 
Tabel 13. Hubungan antara Riwayat mengkonsumsi analgesic/OAINS dengan GGK

\begin{tabular}{|c|c|c|c|c|c|c|c|}
\hline \multirow{2}{*}{$\begin{array}{c}\text { Riwayat } \\
\text { konsumsi } \\
\text { analgesic/OAI } \\
\text { NS }\end{array}$} & \multicolumn{5}{|c|}{ GGK } & \multirow[b]{2}{*}{ OR } & \multirow[b]{2}{*}{$P$ value } \\
\hline & $\mathrm{N}$ & $\begin{array}{l}\text { Stag } \\
\text { e } \\
4\end{array}$ & (\%) & $\begin{array}{l}\text { sta } \\
\text { ge } \\
5\end{array}$ & (\%) & & \\
\hline $\begin{array}{c}\text { Mempunyai } \\
\text { riwayat }\end{array}$ & 32 & 1 & 9,1 & 31 & 63,3 & $\begin{array}{c}0,05 \\
8\end{array}$ & 0,001 \\
\hline $\begin{array}{c}\text { Tidak } \\
\text { mempunyai } \\
\text { riwayat }\end{array}$ & 28 & 10 & 90,9 & 18 & 36,7 & & \\
\hline Total & 60 & 11 & 100 & 49 & 100 & & \\
\hline
\end{tabular}

menunjukkan nilai $p$ value 0,001 ( $p$ value $<0,05)$ yang artinya riwayat mengkonsumsi analgesic/OAINS mempunyai hubungan yang signifikan secara statistik dengan kejadian GGK stage 5 dengan nilai OR sebesar 0,058 yang berarti responden yang mempunyai riwayat mengkonsumsi analgesic/OAINS lebih berisiko menderita GGK stage 5 sebesar 0,058 kali dibandingkan dengan responden yang tidak mempunyai riwayat mengkonsumsi analgesic/OAINS.

Tabel 14. Hubungan antara Riwayat mengkonsumsi minuman suplemen berenergi dengan GGK

\begin{tabular}{|c|c|c|c|c|c|c|c|}
\hline \multirow{2}{*}{$\begin{array}{l}\text { Riwayat } \\
\text { konsumsi } \\
\text { minuman } \\
\text { suplemen }\end{array}$} & \multicolumn{5}{|c|}{ GGK } & \multirow[b]{2}{*}{ OR } & \multirow[b]{2}{*}{$\begin{array}{c}P \\
\text { value }\end{array}$} \\
\hline & $\mathrm{N}$ & $\begin{array}{c}\text { Stage } \\
4\end{array}$ & $(\%)$ & $\begin{array}{c}\text { Stage } \\
5\end{array}$ & $(\%)$ & & \\
\hline $\begin{array}{l}\text { Mempunyai } \\
\text { riwayat }\end{array}$ & 54 & 7 & 63,6 & 47 & 95,9 & 0,074 & 0,008 \\
\hline $\begin{array}{l}\text { Tidak } \\
\text { mempunyai } \\
\text { riwayat }\end{array}$ & 6 & 4 & 36,4 & 2 & 4,1 & & \\
\hline Total & 60 & 11 & 100,0 & 49 & 100,0 & & \\
\hline
\end{tabular}

Hasil analisis bivariat tabel di atas menunjukkan nilai $p$ value 0,008 ( $p$ value $<0,05)$ yang artinya riwayat mengkonsumsi minuman suplemen berenergi mempunyai hubungan yang signifikan secara statistik dengan kejadian GGK stage 5 dengan nilai OR sebesar 0,074 yang berarti responden yang mempunyai riwayat mengkonsumsi minuman suplemen berenergi lebih berisiko menderita GGK stage 5 sebesar 0,074 kali dibandingkan dengan responden yang tidak mempunyai riwayat mengkonsumsi minuman suplemen berenergi.

\section{Analisa Multivariat}

Tabel 15. Analisis Multivariat

\begin{tabular}{|c|c|c|c|c|c|c|}
\hline $\begin{array}{l}\mathrm{N} \\
\mathrm{o}\end{array}$ & Variabel & B & Wald & $P$ value & OR & $\begin{array}{l}95 \% \\
\text { CI }\end{array}$ \\
\hline 1 & Riwayat DM & $-2,288$ & 3,677 & 0,055 & 0,101 & $\begin{array}{l}0,010- \\
1,052\end{array}$ \\
\hline 2 & $\begin{array}{l}\text { Riwayat } \\
\text { mengkonsumsi } \\
\text { analgesic/OAINS }\end{array}$ & 3,394 & 8,321 & 0,004 & 29,789 & $\begin{array}{l}2,968- \\
298,97 \\
4\end{array}$ \\
\hline 3 & $\begin{array}{l}\text { Riwayat } \\
\text { mengkonsumsi } \\
\text { minuman } \\
\text { suplemen } \\
\text { berenergi }\end{array}$ & 3,577 & 6,043 & $0,014^{*}$ & 35,751 & $\begin{array}{l}2,065- \\
619,09 \\
0\end{array}$ \\
\hline
\end{tabular}

Tabel di atas menunjukkan bahwa variabel riwayat mengkonsumsi minuman suplemen berenergi merupakan faktor yang paling dominan mempengaruhi kejadian GGK stage 5 dengan nilai $\mathrm{OR}=35,791$ dan $95 \%$ CI 2,065-619,090.

\section{PEMBAHASAN}

\section{Hubungan Usia dengan Kejadian GGK}

Hasil analisis bivariat menunjukkan nilai $p$ value 0,039 ( $p$ value $<0,05$ ) yang artinya usia mempunyai hubungan yang signifikan secara statistic dengan kejadian GGK stage 5 dengan nilai OR sebesar 0,113 berarti usia lebih dari sama dengan 60 tahun lebih berisiko terkena GGK stage 5 sebesar 0,113 kali dibandingkan dengan responden yang berusia lebih dari sama dengan 60 tahun.

Hasil penelitian di atas sesuai dengan hasil penelitian Restu Pranandari dan Woro Supadmi (2015) dengan hasil $p$ value < $0,05, \quad \mathrm{OR}=2,235, \quad \mathrm{CI}=1,139-4,385$ yang menunjukkan bahwa sfaecara klinik 
pasien usia $>60$ tahun mempuyai risiko 2,2 kali lebih besar mengalami gagal ginjal kronik dibandingkan dengan pasien usia $<60$ tahun. Faktor usia > 60 tahun lebih berisiko mengalami GGK di dukung oleh data dari Riset Kesehatan Dasar (Riskesdas) tahun 2013 prevalensi gagal ginjal kronik di Indonesia sekitar $0,2 \%$. Prevalensi kelompok umur $\geq 75$ tahun dengan $0,6 \%$ lebih tinggi daripada kelompok umur yang lain. Mcclellan dan Flanders (2003 dalam jurnal Restu Pranandari \& Woro Supadmi 2015) membuktikan bahwa faktor risiko gagal ginjal salah satunya adalah umur yang lebih tua (Pranandari \& Woro, 2015).

Hasil penelitian ini didukung oleh teori yang menyatakan semakin bertambah usia, semakin berkurang fungsi ginjal dan berhubungan dengan penurunan kecepatan ekskresi glomerulus dan memburuknya fungsi tubulus. Penurunan fungsi ginjal dalam skala kecil merupakan proses normal bagi setiap manusia seiring bertambahnya usia, namun tidak menyebabkan kelainan atau menimbulkan gejala karena masih dalam batas-batas wajar yang dapat ditoleransi ginjal dan tubuh. Namun, akibat ada beberapa faktor risiko dapat menyebabkan kelainan dimana penurunan fungsi ginjal terjadi secara cepat atau progresif sehingga menimbulkan berbagai keluhan dari ringan sampai berat, kondisi ini disebut gagal ginjal kronik (GGK) atau chronic renal failure (CRF) (Suhardjono, 2001).

\section{Hubungan Jenis Kelamin dengan Kejadian GGK}

Hasil analisis bivariat menunjukkan nilai $p$ value 0,036 ( $p$ value $<0,05)$ yang artinya jenis kelamin mempunyai hubungan yang signifikan secara statistik dengan kejadian GGK stage 5 dengan nilai OR sebesar 5,087 yang berarti responden berjenis kelamin laki-laki lebih berisiko menderita GGK stage 5 sebesar 5,087 kali dibandingkan dengan responden yang berjenis kelamin perempuan.

Hasil penelitian di atas sesuai dengan hasil penelitian Restu Pranandari dan Woro Supadmi (2015) dengan hasil $p$ value $<0,05, \mathrm{OR}=2,003, \mathrm{CI}=1,028-4,023$ yang menunjukkan bahwa secara klinik laki-laki mempunyai risiko mengalami gagal ginjal kronik 2 kali lebih besar daripada perempuan, selain itu hasil penelitian yang dilakukan Noviek Restianika pada tahun 2014 di Ruang Penyakit Dalam Di RSUD dr.Soeroto Kabupaten Ngawi juga diperoleh hasil bahwa rata-rata responden yang menderita gagal ginjal kronik adalah berjenis kelamin laki-laki. Hal ini dimungkinkan karena perempuan lebih memperhatikan kesehatan dan menjaga pola hidup sehat dibandingkan laki-laki, sehingga laki-laki lebih mudah terkena gagal ginjal kronik dibandingkan perempuan. Perempuan lebih patuh dibandingkan laki-laki dalam menggunakan obat karena perempuan lebih dapat menjaga diri mereka sendiri serta bisa mengatur tentang pemakaian obat (Morningstar et al., 2002 dalam jurnal Restu Pranandari \& Woro Supadmi 2015).

\section{Hubungan Riwayat Merokok dengan Kejadian GGK}

Hasil analisis bivariat menunjukkan nilai $p$ value 0,039 ( $p$ value $<0,05)$ yang artinya riwayat merokok mempunyai hubungan yang signifikan secara statistik dengan kejadian GGK stage 5 dengan nilai OR sebesar 5,087 yang berarti responden yang mempunyai 
riwayat merokok lebih berisiko menderita GGK stage 5 sebesar 5,087 kali dibandingkan dengan responden yang tidak mempunyai riwayat merokok.

Hasil penelitian di atas sesuai dengan hasil penelitian Restu Pranandari dan Woro Supadmi (2015) dengan hasil $p$ value $<0,05, \mathrm{OR}=1,987, \mathrm{CI}=1,017-0,347$ yang menunjukkan bahwa secara klinik Pasien gagal ginjal kronik dengan hemodialisis yang mempunyai riwayat merokok mempunyai risiko dengan kejadian gagal ginjal kronik lebih besar 2 kali dibandingkan dengan pasien tanpa riwayat merokok. Hasil penelitian Hidayati (2008) juga menyatakan bahwa bahwa pada perokok aktif maupun pasif secara bermakna meningkatkan risiko kejadian gagal ginjal kronik terminal. Efek merokok fase akut yaitu meningkatkan pacuan simpatis yang akan berakibat pada peningkatan tekanan darah, takikardi, dan penumpukan katekolamin dalam sirkulasi. Pada fase akut beberapa pembuluh darah juga sering mengalami vasokonstriksi misalnya pada pembuluh darah koroner, sehingga pada perokok akut sering diikuti dengan peningkatan tahanan pembuluh darah ginjal sehingga terjadi penurunan laju filtrasi glomerulus dan fraksi filter (Grassi et al., 1994 ; Orth et al., 2000 dalam jurnal Restu Pranandari \& Woro Supadmi 2015).

\section{Hubungan Riwayat dengan Kejadian GGK}

Hasil analisis

\section{Hipertensi}

bivariat

menunjukkan nilai $p$ value $0,016(<0,05)$ yang artinya riwayat penyakit hipertensi mempunyai hubungan yang signifikan secara statistik dengan kejadian GGK stage 5 dengan nilai OR sebesar 0,096 yang berarti responden mempunyai riwayat hipertensi lebih berisiko menderita GGK stage 5 sebesar 0,118 kali dibandingkan dengan responden yang yang tidak mempunyai riwayat hipertensi.

Hasil penelitian di atas sesuai dengan hasil penelitian Restu Pranandari dan Woro Supadmi (2015) dengan hasil $p$ value $<0,05, \mathrm{OR}=4,044, \mathrm{CI}=1,977-8,271$ yang menunjukkan bahwa secara klinik pasien dengan riwayat penyakit hipertensi mempunyai risiko mengalami gagal ginjal kronik 3,2 kali lebih besar daripada pasien tanpa riwayat penyakit hipertensi. Peningkatan tekanan darah berhubungan dengan kejadian penyakit ginjal kronik (Hsu et al., 2005 dalam jurnal Restu Pranandari \& Woro Supadmi 2015).

Hasil penelitian ini diperkuat dengan teori yang menyatakan bahwa hipertensi dapat memperberat kerusakan ginjal telah disepakati yaitu melalui peningkatan tekanan intraglomeruler yang menimbulkan gangguan struktural dan gangguan fungsional pada glomerulus.Tekanan intravaskular yang tinggi dialirkan melalui arteri aferen ke dalam glomerulus, dimana arteri aferen mengalami konstriksi akibat hipertensi (Susalit, 2003).

\section{Hubungan Riwayat DM dengan Kejadian GGK \\ Hasil analisis bivariat} menunjukkan nilai $p$ value 0,016 ( $p$ value $<0,05$ ) yang artinya riwayat penyakit DM mempunyai hubungan yang signifikan secara statistik dengan kejadian GGK stage 5 dengan nilai OR sebesar 11,304 yang berarti responden yang mempunyai riwayat penyakit DM lebih berisiko menderita GGK stage 5 sebesar 11 kali dibandingkan dengan responden yang tidak mempunyai riwayat penyakit DM. 
Hasil penelitian di atas sesuai dengan hasil penelitian Restu Pranandari dan Woro Supadmi (2015) dengan hasil $p$ value $<0,05, \quad \mathrm{OR}=5,395, \mathrm{CI}=2,254-$ 12,916 yang menunjukkan bahwa secara klinik riwayat penyakit diabetes melitus mempunyai risiko terhadap kejadian gagal ginjal kronik 4,1 kali lebih besar dibandingkan dengan pasien tanpa riwayat penyakit diabetes melitus.

Hasil penelitian ini diperkuat dengan teori yang menyatakan bahwa Salah satu akibat dari komplikasi diabetes melitus adalah penyakit mikrovaskuler, diantaranya nefropati diabetika yang merupakan penyebab utama gagal ginjal terminal. Berbagai teori tentang patogenesis nefropati seperti peningkatan produk glikosilasi dengan proses non-enzimatik yang disebut AGEs (Advanced Glucosylation End Products), peningkatan reaksi jalur poliol (polyol pathway), glukotoksisitas, dan protein kinase $\mathrm{C}$ memberikan kontribusi pada kerusakan ginjal. Kelainan glomerulus disebabkan oleh denaturasi protein karena tingginya kadar glukosa, hiperglikemia, dan hipertensi intraglomerulus. Kelainan atau perubahan terjadi pada membran basalis glomerulus dengan proliferasi dari sel-sel mesangium. Keadaan ini akan menyebabkan glomerulosklerosis dan berkurangnya aliran darah, sehingga terjadi perubahan-perubahan pada permeabilitas membran basalis glomerulus yang ditandai dengan timbulnya albuminuria (Sue et al., 2000 dalam jurnal Restu Pranandari \& Woro Supadmi 2015). Beberapa penelitian lainnya juga meendukung hal ini bahwa diabetes melitus lebih banyak mengarah pada penyakit-penyakit oklusi arteri diameter kecil seperti ekstrimitas bawah, gagal ginjal, retinopati, dan saraf kranial atau perifer (Jorgensen, 1994 dalam jurnal Restu Pranandari \& Woro Supadmi 2015).

\section{Hubungan Riwayat Mengkonsumsi Analgesik/OAINS dengan Kejadian GGK}

Hasil analisis bivariat menunjukkan nilai $p$ value 0,001 ( $p$ value $<0,05)$ yang artinya riwayat mengkonsumsi analgesic/OAINS mempunyai hubungan yang signifikan secara statistik dengan kejadian GGK stage 5 dengan nilai OR sebesar 0,058 yang berarti responden yang mempunyai riwayat mengkonsumsi analgesic/OAINS lebih berisiko menderita GGK stage 5 sebesar 0,058 kali dibandingkan dengan responden yang tidak mempunyai riwayat mengkonsumsi analgesic/OAINS.

Hasil penelitian di atas sesuai dengan hasil penelitian Restu Pranandari dan Woro Supadmi (2015) dengan hasil $p$ value $<0,05, \mathrm{OR}=0,160, \mathrm{CI}=0,074-0,347$ yang menunjukkan bahwa secara statistik riwayat mengkonsumsi analgesic/OAINS mempunyai hubungan dengan kejadian gagal ginjal kronik.

Beberapa bukti epidemiologi menunjukkan bahwa ada hubungan antara penggunaan obat analgetik dan OAINS secara berlebihan dengan kejadian kerusakan ginjal atau nefropati. Nefropati analgetik merupakan kerusakan nefron akibat penggunaan analgetik. Penggunaan obat analgetik dan OAINS untuk menghilangkan rasa nyeri dan menekan radang (bengkak) dengan mekanisme kerja menekan sintesis prostaglandin. Akibat penghambatan sintesis prostaglandin menyebabkan vasokonstriksi renal, menurunkan aliran darah ke ginjal, dan potensial menimbulkan iskemia glomerular. Obat 
analgetik dan OAINS juga menginduksi kejadian nefritis interstisial yang selalu diikuti dengan kerusakan ringan glomerulus dan nefropati yang akan mempercepat progresifitas kerusakan ginjal, nekrosis papilla, dan penyakit gagal ginjal kronik. Obat analgetika dan OAINS menyebabkan nefrosklerosis yang berakibat iskemia glomerular sehingga menurunkan GFR kompensata dan GFR nonkompensata atau gagal ginjal kronik yang dalam waktu lama dapat menyebabkan gagal ginjal terminal (Fored et al., 2003 dalam jurnal Restu Pranandari \& Woro Supadmi 2015).

\section{Hubungan Riwayat Mengkonsumsi Minuman Suplemen Berenergi dengan Kejadian GGK}

Hasil analisis bivariat menunjukkan nilai $p$ value 0,008 ( $p$ value $<0,05)$ yang artinya riwayat mengkonsumsi minuman suplemen berenergi mempunyai hubungan yang signifikan secara statistik dengan kejadian GGK satge 5 dengan nilai OR sebesar 0,074 yang berarti responden yang mempunyai riwayat mengkonsumsi minuman suplemen berenergi lebih berisiko menderita GGK satge 5 sebesar 0,074 kali dibandingkan dengan responden yang tidak mempunyai riwayat mengkonsumsi minuman suplemen berenergi

Hasil penelitian di atas sesuai dengan hasil penelitian Restu Pranandari dan Woro Supadmi (2015) dengan hasil $p$ value $<0,05, \mathrm{OR}=0,450, \mathrm{CI}=0,230-0,880$ yang menunjukkan bahwa secara statistik riwayat mengkonsumsi minuman suplemen berenergi mempunyai hubungan dengan kejadian gagal ginjal kronik.
Hasil penelitian ini diperkuat dengan hasil penelitian Hidayati (2008) yang menyakatan beberapa psikostimulan (kafein dan amfetamin) terbukti dapat mempengaruhi ginjal. Amfetamin dapat mempersempit pembuluh darah arteri ke ginjal sehingga darah yang menuju ke ginjal berkurang. Akibatnya, ginjal akan kekurangan asupan makanan dan oksigen. Keadaan sel ginjal kekurangan oksigen dan makanan akan menyebabkan sel ginjal mengalami iskemia dan memacu timbulnya reaksi inflamsi yang dapat berakhir dengan penurunan kemampuan sel ginjal dalam menyaring darah (Hidayati, 2008).

\section{Faktor yang paling dominan mempengaruhi terjadinya GGK}

Faktor riwayat mengkonsumsi minuman suplemen berenergi merupakan faktor yang paling dominan mempengaruhi kejadian GGK dengan nilai dengan nilai $\mathrm{OR}=35,791$ dan $95 \% \mathrm{CI}$ 2,065-619,090. Hasil penelitian ini sesuai dengan penelitian Hidayati (2008) dimana konsumsi suplemen energi mempunyai nilai $(\mathrm{OR}=7$; $\mathrm{CI}=2.53-17.35 ; \mathrm{p}<0,05)$ yang menyatakan bahwa riwayat mengkonsumsi minuman suplemen berenergi mempunyai hubungan yang signifikan dengan kejadian GGK. Selain hasil penelitian dari Hidayati, hasil penelitian Noviek Restianika (2014) juga menyatakan bahwa faktor yang paling berpengaruh terhadap kejaian GGK stage 5 salah satunya adalah riwayat konsumsi minuman suplemen berenergi. Hasil Penelitian dari Nugroho (2015) juga menyatakan bahwa terdapat hubungan yang signifikan antara konsumsi suplemen energi dengan stadium Chronic Kidney Disease. Hal tersebut disebabkan karena beberapa psikostimulan (kafein dan 
amfetamin terbukti dapat mempengaruhi fungsi ginjal. Amfetamin dapat menyempitkan pembuluh darah arteri ke ginjal sehingga darah yang menuju ke ginjal berkurang akibatnya ginjal akan kekurangan asupan makanan dan oksigen. Keadaan sel ginjal kekurangan oksigen dan makanan akan menyebabkan sel ginjal mengalami iskemia dan memacu timbulnya reaksi inflamasi yang dapat berakhir dengan penurunan kemampuan sel ginjal dalam menyaring darah (Suhardjono, 2001).

\section{KESIMPULAN DAN SARAN}

Hasil penelitian yang telah dilakukan oleh peneliti tentang analisa faktor risiko penyebab terjadinya penyakit GGK di ruang Hemodialisa RS Dr. Moewardi Surakarta dapat disimpulkan bahwa faktor-faktor yang mempengaruhi kejadian GGK stage 5 pada responden yang melakukan hemodialisis di Ruang Hemodialisa RS Dr. Moewardi antara lain usia lebih dari sama dengan 60 tahun $(91,7 \%)$, jenis kelamin laki-laki $(53,3 \%)$, riwayat merokok $(53,3 \%)$, riwayat hipertensi $(75,0 \%)$, riwayat DM $(55,0 \%)$, riwayat mengkonsumsi analgesic/OAINS (53,3 $\%$ ), riwayat mengkonsumsi minuman suplemen berenergi yaitu sebanyak $(90,0 \%)$; faktor usia responden mempunyai hubungan yang signifikan dengan kejadian GGK satge 5 di Ruang Hemodialisa RS Dr. Moewardi dengan nilai $\mathrm{p}$ value 0,039 ; faktor jenis kelamin responden mempunyai hubungan yang signifikan dengan kejadian GGK stage 5 di Ruang Hemodialisa RS Dr. Moewardi dengan nilai $p$ value 0,036 ; faktor riwayat merokok pada responden mempunyai hubungan yang signifikan dengan kejadian GGK stage 5 di Ruang
Hemodialisa RS Dr. Moewardi dengan nilai $\mathrm{p}$ value 0,036; faktor riwayat hipertensi pada responden mempunyai hubungan yang signifikan dengan kejadian GGK stage 5 di Ruang Hemodialisa RS Dr. Moewardi dengan nilai $\mathrm{p}$ value 0,021 ; faktor riwayat DM pada responden mempunyai hubungan yang signifikan dengan kejadian GGK stage 5 di Ruang Hemodialisa RS Dr. Moewardi dengan nilai $\mathrm{p}$ value 0,016 ; faktor riwayat mengkonsumsi analgesic/OAINS pada responden mempunyai hubungan yang signifikan dengan kejadian GGK stage 5 di Ruang Hemodialisa RS Dr. Moewardi dengan nilai $p$ value 0,001 ; faktor riwayat mengkonsumsi minuman suplemen berenergi pada responden mempunyai hubungan yang signifikan dengan kejadian GGK satge 5 di Ruang Hemodialisa RS Dr. Moewardi dengan nilai $\mathrm{p}$ value 0,008 dan faktor yang paling dominan terhadap kejadian GGK satge 5 pada responden yang menjalani hemodialysis di Ruang Hemodialisa RS Dr. Moewardi adalah riwayat mengkonsumsi minuman suplemen berenergi dengan nilai OR=35,791 dan 95\% CI 2,065-619,090.

Saran bagi Institusi Pendidikan Keperawatan disarankan dapat menjadikan hasil penelitian ini sebagai tambahan informasi dan bahan masukkan mengenai konsep yang mendalam tentang GGK yaitu tentang faktor-faktor risiko penyebab kejadian GGK. Bagi tenaga kesehatan di pelayanan kesehatan masyarakat dan perawat di rumah sakit dapat menggunakan hasil penelitian ini sebagai bahan tambahan informasi dan referensi tambahan dalam melakukan penyuluhan kesehatan tentang faktorfaktor risiko penyebab GGK. Bagi Peneliti Selanjutnya yaitu apabila dilakukan penelitian dengan topik yang hampir sama 
disarankan untuk menambah variabel lain yaitu riwayat obesitas dan memperbanyak jumlah sampel, selain itu disarankan untuk menggunakan variabel lain yaitu lamanya kebiasaan mengkonsumsi minuman suplemen berenergi dengan kejadian GGK; pada saat pengambilan data variabel riwayat merokok, riwayat hipertensi, riwayat DM, riwayat mengkonsumsi analgesic/ OAINS, riwayat mengkonsumsi minuman suplemen berenergi sebaiknya diberi keterangan lamanya kebiasaan merokok, menderita hipertensi, menderita DM, kebiasaan mengkonsumsi analgesic/ OAINS, kebiasaan mengkonsumsi minuman suplemen berenergi, sehingga dalam pembahasan didapatkan hasil yang lebih detail; dan pada saat mengkaji riwayat mengkonsumsi minuman suplemen berenergi sebaiknya dikaji pula frekuensi konsumsi minuman suplemen berenergi tersebut.

\section{DAFTAR RUJUKAN}

Dahlan, Sopiyudin.(2009).Statistik untuk Kedokteran Kesehatan Deskriptif, Bivariat, dan Multivariat Dilengkapi dengan Menggunakan SPSS Edisi 4.Jakarta:Salemba Medika.

\begin{tabular}{cc} 
Dinas & \multicolumn{1}{c}{ Kesehatan Jawa } \\
& Tengah.(2008).Prevalensi \\
& Kejadian Gagal Ginjal Kronik Di \\
& Provinsi $\quad$ Jawa \\
& Tengah.http://prevalensi/gagal \\
& ginjal kronik/provinsi \\
& jateng/2008/pdf/(online).diakses \\
tanggal 16 Januari 2016.
\end{tabular}

Hastono, S.P.(2007).Analisis Data Kesehatan.Jakarta:Fakultas Kesehatan Masyarakat UI.
Hidayat, A.A.(2014). Metode Penelitian Kebidanann dan Teknik Analisa Data. Jakarta : Salemba Medika.

Hidayati, Titiek.(2008).Hubungan Antara Hipertensi, Merokok dan Minuman Suplemen Energi dan Kejadian Penyakit Ginjal Kronik.Tesis, Program Pasca Sarjana Universitas Gajah Mada, Yogyakarta.90-102.

Kemenkes RI.(2007).Prevalensi kejadian Gagal Ginjal Kronik Di Rumah Sakit Indonesia Tahun2006.http://prevalensi/gagal ginjalkronik/Indonesia/tahun 2006/(online).diakses tanggal 15 Januari 2016.

Nugroho, Sri Hananto P.(2015).Hubungan Frekuensi Konsumsi Suplemen Energi dengan Stadium Chronic Kidney Disease Di Ruang Hemodialisa RSUD Ibnu Sina Gresik. Skripsi, Program Studi Ilmu Keperawatan STIKES Muhammadiyah Lamongan vol. 07, No. 01.

Nursalam. (2013). Metodologi penelitian Ilmu Keperawatan. Jakarta: Salemba Medika.

Nursalam. (2009). Metodologi penelitian Ilmu Keperawatan. Jakarta: Salemba Medika

Perhimpunan Nefrologi Indonesia (PERNEFRI). (2011). Konsensus Peritoneal Dialisis Pada Penyakit Ginjal Kronis.http://www. $4^{\text {th }}$ Annual Report Of IRR 2011.pdf (online).diakses tanggal 16 Januari 2016.

Pranandari, Restu \& Woro Supadmi. (2015). Faktor Risiko Gagal Ginjal Kronik Di Unit Hemodialisis Rsud Wates Kulon Progo.http:www.jurnal/gagal ginjal kronik/2014 (Online), 
diperoleh 18 Januari 2016 pukul 11.00 WIB.

Rahardjo P, Susalit E, Suharjono.(2009).Hemodialisis.In : Sudoyo A.W ,Setiyohadi B, Alwi I, Simadibrata KM, Setiati S ,eds. Buku Ajar Ilmu Penyakit Dalam. 5th ed. Pusat Penerbitan Departemen Ilmu Penyakit Dalam Fakutas Kedokteran Universitas Indonesia.

Rekam Medis RSDM.(20152016).Jumlah Penderita Gagal Ginjal Kronik Tahun 2015 dan 2016.

Restianika, Noviek.(2014). Faktor Yang Berhubungan Dengan Kejadian Gagal Ginjal Kronik Pada Pasien Rawat Inap Ruang Penyakit Dalam Di RSUD Dr.Soeroto Kabupaten

Ngawi.http:www.jurnal/gagal ginjal kronik/2014 (Online), diperoleh 18 Januari 2016 pukul 11.00 WIB.

Riset Kesehatan Dasar (RISKESDAS). (2013). Prevalensi Gagal Ginjal Kronik

Indonesia.http://prevalensi gagal ginjal kronik di Indonesia tahun 2013//pdf/(online).diakses tanggal 16 Januari 2016.

Suhardjono, Lydia, A., Kapojos, E.J., Sidabutar, R.P.(2001).Gagal Ginjal Kronik Buku AjarIlmu Penyakit Dalam Jilid II Edisi 3. Jakarta: FKUI.

Sukandar E.(2006). Terapi Pengganti Ginjal dengan Dialisis. Dalam: Nefrologi Klinik. Edisi III. FK UNPAD.

Susalit, E.(2003). Rekomendasi Baru Penatalaksanaan Penyakit Ginjal Kronik. In: Penyakit Ginjal
Kronik \& Glomerulonepati: Aspek Klinik \& Patologi Gnjal Pengelolaan Hipertensi Saat Ini.. Jakarta:Perhimpunan 